\title{
How Relevant Is It to Use Mineral Proxies to Mimic the Atmospheric Reactivity of Natural Dust Samples? A Reactivity Study Using $\mathrm{SO}_{2}$ as Probe Molecule
}

\author{
Darya Urupina *, Manolis N. Romanias *(D) and Frederic Thevenet (D) \\ IMT Lille Douai, University Lille, SAGE, 59000 Lille, France; frederic.thevenet@imt-lille-douai.fr \\ * Correspondence: darya.urupina@imt-lille-douai.fr (D.U.); emmanouil.romanias@imt-lille-douai.fr (M.N.R.)
}

\section{check for}

updates

Citation: Urupina, D.; Romanias, M.N.; Thevenet, F. How Relevant is it to Use Mineral Proxies to Mimic the Atmospheric Reactivity of Natural Dust Samples? A Reactivity Study Using $\mathrm{SO}_{2}$ as Probe Molecule. Minerals 2021, 11, 282. https:// doi.org/10.3390/min11030282

Academic Editors:

Athanasios Godelitsas and Juan Antelo

Received: 7 December 2020

Accepted: 4 March 2021

Published: 9 March 2021

Publisher's Note: MDPI stays neutral with regard to jurisdictional claims in published maps and institutional affiliations.

Copyright: (c) 2021 by the authors. Licensee MDPI, Basel, Switzerland. This article is an open access article distributed under the terms and conditions of the Creative Commons Attribution (CC BY) license (https:// creativecommons.org/licenses/by/ $4.0 /)$.

\begin{abstract}
The experimental investigation of heterogeneous atmospheric processes involving mineral aerosols is extensively performed in the literature using proxy materials. In this work we questioned the validity of using proxies such as $\mathrm{Fe}_{2} \mathrm{O}_{3}, \mathrm{FeOOH}, \mathrm{Al}_{2} \mathrm{O}_{3}, \mathrm{MgO}, \mathrm{CaO}, \mathrm{TiO}_{2}, \mathrm{MnO}_{2}, \mathrm{SiO}_{2}$, and $\mathrm{CaCO}_{3}$ to represent the behavior of complex mixtures of minerals, such as natural desert and volcanic dusts. Five volcanic dusts and three desert dusts were compared to a number of metal oxides, commonly used in the literature to mimic the behavior of desert dusts in the ability to form sulfites and sulfates on the surface exposed to $\mathrm{SO}_{2}$ gas. First, all samples were aged at room temperature, atmospheric pressure, under controlled experimental conditions of $175 \mathrm{ppm} \mathrm{SO}_{2}$ for $1 \mathrm{~h}$ under $30 \%$ of relative humidity. Second, they were extracted with $1 \%$ formalin and analyzed by High-Performance Liquid Chromatography (HPLC) to quantify and compare the amount of sulfites and sulfates formed on their surfaces. It was evidenced that under the experimental conditions of this study neither one selected pure oxide nor a mixture of oxides can adequately typify the behavior of complex mixtures of natural minerals. Therefore, to evaluate the real-life impact of natural dust on atmospheric processes it is of vital importance to work directly with the natural samples, both to observe the real effects of desert and volcanic dusts and to evaluate the relevancy of proposed proxies.
\end{abstract}

Keywords: sulfite; sulfate; mineral dust; volcanic particles; desert dust; mineral proxies

\section{Introduction}

Airborne mineral particulate of desert and volcanic origin represents an important component of the atmosphere. Every year, from 1000 to 3000 million tons of soil dust are mobilized by high winds in the arid and semiarid regions of the world, such as Gobi and Sahara [1]. These aerosols can travel thousands of kilometers, crossing oceans and continents. As such, the role of Sahara dust was highlighted in fertilization of the Amazon rainforest [2]. At the average of 33 million tons per year, volcanic particles represent an additional, seemingly minor source of mineral aerosol; nevertheless, high variability of volcanic eruptions can easily increase the contribution to 10,000 million tons on a year of high volcanic activity [3]. A number of eruptions marked the 20th century, such as the 1980 eruption of Mt. St. Helens, in the USA and the $1991 \mathrm{Mt}$. Pinatubo eruption in the Philippines [4,5]. At any given moment as many as 20 volcanoes around the globe might be erupting [6]. Just as mineral dust, volcanic particles can be carried over large distances, sometimes exceeding the expected sedimentation distance [7]. As an example, during the 2010 Eyjafjallajökull eruption, $90 \mu \mathrm{m}$ particles were found as far as $1300 \mathrm{~km}$ from the vent [8].

Airborne dust is a key player in the Earth's system. It modulates the global temperature directly by scattering, absorbing and re-emitting solar radiation, and indirectly by acting as a cloud condensation nuclei (CCN) or ice nuclei (IN) [9]. Cloud and precipitation formation ultimately affects the hydrological cycle [9-11]. In addition, dust particles can serve as a long-range transporting carrier for many species adsorbed on its surface [12-15]. 
While transferring these species, mineral dust might participate in different heterogeneous reactions that can potentially influence the balance of atmospheric species. In the troposphere, dust particles can act both as primary pollutant and as pollutant scavenger [1,9]. In addition, mineral and volcanic particles provide a source of nutrients to the oceans in the form of bioavailable iron, which in turn stimulates biological activity and affects the global carbon cycle $[9,16,17]$.

Since mineral dust originates from the soil and/or the underlying rock basement, it shares with it a similar elemental composition. The major components of mineral dust are relatively uniform and, expressed as oxides, consist of about $60 \% \mathrm{SiO}_{2}$ and $10-15 \%$ of $\mathrm{Al}_{2} \mathrm{O}_{3}$, followed by $\mathrm{Fe}_{2} \mathrm{O}_{3}(6 \%), \mathrm{MgO}(6 \%)$ and $\mathrm{CaO}(3 \%)$ [1]. Note that the convention of reporting elemental composition in the percent oxide form dates back to when minerals and rocks were analyzed using wet-chemical methods to precipitate an element. The precipitate was oxidized under high temperature and the results were weighed as the oxide. However, it should be noted that, although customary, representation of soil composition in the form of oxides is largely artificial and is not representative of the actual mineralogy of soils [18].

Airborne desert dust has a complex composition and consists of quartz, feldspars, micas, chlorite, kaolinite, illite, smectite, palygorskyte, calcite, dolomite, gypsum, halite, opal, and mixed-layer clay minerals [1]. The mineral composition of volcanic particles reflects the composition of magma from which it was generated and consists mostly of aluminosilicate glassy particles, minerals and rock fragments [6,19]. Minerals in the volcanic ash are found as individual particles as well as embedded micro-minerals in particles dominated by a glassy matrix [20]. Mineral phases are prevalently constituted by silicate minerals, such as feldspar, olivine, pyroxene, hornblende, biotite, and oxides [6]. Low abundance of crystalline mineral phases in volcanic particles makes their determination and quantification difficult. The major difference between desert and volcanic origin materials comes from the fact that volcanic particles contain a high share of amorphous material (glass particle components may vary between 40 and $100 \mathrm{wt} . \%$ ), while desert dust is mostly crystalline [19].

Due to the crystalline nature of desert dusts, authors investigating their behavior often substitute natural samples for simple metal oxides, in order to mimic the behavior of complex minerals. In the most recent IUPAC review of kinetic data on heterogeneous reactions on dust surfaces, only $30 \%$ of the studies were carried out using natural desert dusts and none dealt with volcanic samples [21]. Thus, kinetic and mechanistic data on natural mineral samples are very limited and their reactivity is often studied by using mainly "reactive components", such as metal oxides, hydroxides, and carbonates: $\mathrm{Fe}_{2} \mathrm{O}_{3}, \mathrm{FeOOH}$, $\mathrm{Al}_{2} \mathrm{O}_{3}, \mathrm{MgO}, \mathrm{CaO}, \mathrm{TiO}_{2}, \mathrm{MnO}_{2}, \mathrm{SiO}_{2}, \mathrm{CaCO}_{3}$ [1,21-30]. The investigations of reactivity of volcanic particles are more commonly carried out using aluminosilicate amorphous material [19]. Oftentimes a single component or a mixture of several components are used to approximate behavior of complex, multivariable desert and volcanic materials. The important advantage of using proxies comes from simplifying the system of study in order (i) to elucidate mechanistic details of complex heterogeneous reactions, (ii) to have more control of the experimental conditions, and (iii) to obtain kinetic and thermodynamic data with a considerable level of accuracy. The kinetic or mechanistic results of the studies using surrogates are then used to estimate the atmospheric implication of the reactions studied and to elucidate their atmospheric impact. However, to which point is it appropriate to use simplified surrogates in order to mimic the behavior of complex mineral mixtures? And do the values obtained by using proxies correctly describe atmospheric processes?

To respond to the above questions in the framework of the current study, $\mathrm{SO}_{2}$ was used as a probe molecule to investigate its interactions with a wide variety of mineral samples (including surrogates, clays, and natural samples). The choice of using $\mathrm{SO}_{2}$ is twofold. First, it is an important widely studied atmospheric molecule [12,31-37]. Second, multiple, sometimes conflicting trends in uptake of $\mathrm{SO}_{2}$ and evaluation of influence of difference variables, such as relative humidity $(\mathrm{RH})$, have been reported in the literature while using different proxies for atmospheric dust [12,21-30,38]. For instance, for a mixture of two pure 
metal oxides, alumina and hematite, two opposite effects on sulfate yields in respect to each individual component are observed: synergistic effect for hematite (higher sulfate yields for hematite-rich mixtures compared to theoretical calculation based on its contribution) and antagonistic effect for alumina (lower sulfate yields for alumina-rich mixtures compared to theoretical calculation based on its contribution) [24]. It should be noted that in one of our recent papers we have cited and discussed the major body of literature dealing with the uptake of $\mathrm{SO}_{2}$ on mineral and volcanic dusts under atmospheric relevant conditions [39]. In order to further examine relevance of using proxies, heterogeneous interactions of $\mathrm{SO}_{2}$ gas with 20 different mineral samples such as commonly used proxies, clays, and a number of natural desert and volcanic particles were investigated. In particular, the mineral samples were aged for $1 \mathrm{~h}$ with $175 \mathrm{ppm}$ of $\mathrm{SO}_{2}, 30 \%$ of $\mathrm{RH}$. The sulfites and sulfates formed on the surface were identified and quantified using a recently developed method based on HPLC analysis [40].

\section{Materials and Methods}

\subsection{Volcanic Samples, Desert Dusts and Metal Oxides}

Five volcanic samples come from different locations in Iceland. The properties of

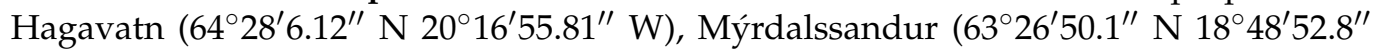
$\mathrm{W})$, Maelifellssandur $\left(63^{\circ} 48^{\prime} 48.7^{\prime \prime} \mathrm{N} 19^{\circ} 07^{\prime} 42.5^{\prime \prime} \mathrm{W}\right)$ and Dyngjusandur $\left(64^{\circ} 50^{\prime} 41.885^{\prime \prime}\right.$ $\mathrm{N} 16^{\circ} 59^{\prime} 40.78^{\prime \prime} \mathrm{W}$ ) volcanic particles are described by Arnalds et al. [41]. Overall, these locations are subjected to extremely large aeolian erosion due to frequent dust storms and have extensive areas (10 to $\left.140 \mathrm{~km}^{2}\right)$, hence providing a large supply (30-40 million tons annually) of volcanic particles to the atmosphere [41]. Samples were collected from the top surface layer of each area and did not come in contact with soil or other organics. The fifth sample of Eyjafjallajökull $\left(63^{\circ} 33^{\prime} 50.4^{\prime \prime} \mathrm{N} 19^{\circ} 27^{\prime} 28.8^{\prime \prime} \mathrm{W}\right)$ volcanic ash was collected and stored dry during the second phase of the explosive-effusive volcanic eruption on April 27, 2010. The composition of this fresh volcanic sample has been characterized by Gislason et al. [42]. Morphology of the v-dust samples was analyzed earlier by Scanning Electron Microscopy (SEM) carried out on a Hitachi S-4300SE/N SEM (Hitachi, Berkshire, UK) in high vacuum mode [39]. Dust from Hagavatn, Mýrdalssandur, Maelifellssandur and Dyngjusandur samples range from 10 to $50 \mu \mathrm{m}$ in diameter, while Eyjafjallajökull sample exhibits larger particle size with many particles reaching $500 \mu \mathrm{m}$ in diameter. Information on the mineralogical composition the $\mathrm{PM}_{10}$ fraction of Hagavatn, Mýrdalssandur, Maelifellssandur and Dyngjusandur samples has been recently provided by Baldo et al. [43].

Three desert mineral dust samples of contrasted elemental compositions come from various regions of the Earth: M'Bour (Senegal), Gobi desert (China), and commercially available Arizona Test Dust (USA). M'Bour natural mineral dust was collected close to the city of $\mathrm{M}^{\prime}$ Bour in Senegal, West Africa $\left(14^{\circ} 25^{\prime} 22.08^{\prime \prime} \mathrm{N} 16^{\circ} 57^{\prime} 55.44^{\prime \prime} \mathrm{W}\right)$. It comes from the Sahara and Sahel region, characterized as the largest source of atmospheric mineral dust that, with the annual median emissions of about 1000 million tons a year, contributes to about $62 \%$ of the total global dust emissions in the atmosphere $[44,45]$. The sample was sieved (using a shaking siever) after collection and the fraction below $100 \mu \mathrm{m}$ was used for the investigations. The Gobi mineral desert dust sample comes from the Gobi Desert, Ningxia Province, China $\left(36^{\circ} 29^{\prime} 14.39^{\prime \prime} \mathrm{N} 107^{\circ} 28^{\prime} 30.75^{\prime \prime} \mathrm{E}\right)$ [46]. This area represents another major source of atmospheric mineral dust [44]. For this aeolian sample the sieved fraction below $100 \mu \mathrm{m}$ also was used for further analyses. In addition, the commercially available nominal 0-3 $\mu \mathrm{m}$ Arizona Test Dust (ID 12332M), (ATD, Powder Technology Inc., Arden Hills, MN, USA) collected on October 17, 2014, was used for the research.

A number of clay minerals were used for comparison reasons while searching for the origin of specific behaviors observed in desert dusts. Atmospheric loadings of clay dusts are among the largest (i.e., ca. 9 million tons), accounting for more than a half of total dust loading estimated at 19.2 million tons [47]. The emission fluxes of clay dusts are also the largest, accounting for almost half of the total dust flux (i.e., ca. 800 million 
tons per year) and providing a large and continuous supply of fresh clay dusts to the atmosphere [47]. Two commercially available clay samples, kaolinite (CAS: 1318-74-7, Lot\# BCBS7473V) and montmorillonite K-10 (CAS: 1318-93-0, Lot\# 14772-106) natural clays, were purchased from Sigma-Aldrich, St. Louis, MO, U.S. The third clay sample, mainly composed of illite (85-90\% purity) (CAS\# 12173-60-3), was obtained from Clay Mineral Society, Aurora, CO, USA and contains 10-15\% of quartz. All three minerals are phyllosilicates whose structure is characterized by varying arrangements of alumina and silica sheets stacked in repeating layers [48]. Kaolinite $\left(\mathrm{Al}_{2} \mathrm{Si}_{2} \mathrm{O}_{5}(\mathrm{OH})_{4}\right)$ is a 1:1 type clay mineral in which each layer contains one silica and one alumina sheet held together by shared oxygen atoms, while montmorillonite $\left((\mathrm{Na}, \mathrm{Ca})_{0.33}(\mathrm{Al}, \mathrm{Mg})_{2} \mathrm{Si}_{4} \mathrm{O}_{10}(\mathrm{OH})_{2} \cdot \mathrm{nH}_{2} \mathrm{O}\right)$ and illite $\left(\mathrm{K}, \mathrm{H}_{3} \mathrm{O}\right)(\mathrm{Al}, \mathrm{Mg}, \mathrm{Fe})_{2}(\mathrm{Si}, \mathrm{Al})_{4} \mathrm{O}_{10}\left[(\mathrm{OH})_{2},\left(\mathrm{H}_{2} \mathrm{O}\right)\right]$ are $2: 1$ clays, where the alumina sheet is sandwiched between two silica sheets. Kaolinite is unique relative to illite and montmorionite because the external surface of its alumina sheet contains structural hydroxyl groups [48]. Kaolinite and illite have a very low ability to adsorb water, while montmorillonite has a high adsorption capacity [48].

Pure mineral oxides include silica gel $\left(\mathrm{SiO}_{2}, 98 \%\right.$ purity) (Merck, Darmstadt, Germany, Lot\# TA565954 912), quartz ( $\left.\mathrm{SiO}_{2}\right)$ (Sigma-Aldrich, St. Louis, MO, U.S., CAS 14808-60-7, Lot\# BCBZ9191), iron oxide $\left(\mathrm{Fe}_{3} \mathrm{O}_{4}, 99.99 \%\right.$ purity) (Sigma-Aldrich, St. Louis, MO, USA, CAS 1317-61-9, Lot\# MKBC3159V), goethite (FeOOH, 30-63\% Fe) (Sigma-Aldrich, St. Louis, MO, USA, CAS 20344-49-4, Lot\# BCCB4398), calcium oxide (CaO, 99.9\% purity) (Merck, Darmstadt, Germany, CAS 1306-78-8, Lot\# MKBW2071V), aluminum oxide $\left(\mathrm{Al}_{2} \mathrm{O}_{3}\right)$ (SigmaAldrich, St. Louis, MO, U.S., CAS 1344-28-1, Lot\# STBC4668V), titanium dioxide $\left(\mathrm{TiO}_{2}\right.$, 99.5\% purity) (Evonik industries, Essen, Germany), calcium carbonate $\left(\mathrm{CaCO}_{3}, 98 \%\right.$ purity) (Sigma-Aldrich, St. Louis, MO, USA, CAS 471-34-1, Lot\# MKBV0812V), and magnesium oxide (MgO, 98-100.5\% purity) (Sigma-Aldrich, St. Louis, MO, USA, CAS 1309-48-4, Lot\# SZBF2170V).

\subsection{Characterization of the Samples}

Elemental Chemical composition/The bulk elemental composition of the natural samples of desert and volcanic samples used in this study was determined by ICP-MS using a Perkin Elmer NeXion 300x spectrometer (Perkin Elmer, Villebon-sur-Yvette, France); the results are presented in Table 1 . Prior to the analysis, from 2 to $7 \mathrm{mg}$ of each sample was treated in a mixture of acids $\left(\mathrm{HF} / \mathrm{HNO}_{3} / \mathrm{H}_{2} \mathrm{O}_{2}\right)$ in a microwave oven (Milestone Ultrawave) at $500 \mathrm{~K}$ and 35 bar for $15 \mathrm{~min}$ [49]. Six measurements per sample were performed to evaluate their chemical heterogeneity. Repeated measurements were carried out on acid blanks, quality-control standard solutions and standard reference material (NIST SRM 1648a and SRM 2584) to evaluate detection limits, accuracy and to validate the whole procedure. In addition, the composition of the samples in the topmost 2 to 10 nanometers of the surface in terms of relative concentrations (in at.\%) of $\mathrm{O}, \mathrm{Si}, \mathrm{Fe}, \mathrm{Ca}$, $\mathrm{Al}, \mathrm{Mg}, \mathrm{Ti}, \mathrm{Na}, \mathrm{K}$, and $\mathrm{Mn}$, was analyzed by X-ray photoelectron spectroscopy (XPS) using a Kratos Axis Ultra instrument (Kratos Analytical, Manchester, United Kingdom). High resolution scans at a pass energy of $40 \mathrm{eV}$ were acquired for C1s, O1s, Si2p, Al2p, Fe2p, Mg2p, Ca2p, Na1s, K2p, Ti2p, and Mn2p using a monochromatic Al X-ray beam centered at $1486.6 \mathrm{eV}$. Data treatment was performed using the CasaXPS software program (Kratos Analytical, Manchester, UK). The binding energy scale was calibrated by assigning a value of $284.8 \mathrm{eV}$ to the $\mathrm{C} 1$ s peak for adventitious carbon. The obtained results represented in $\%$ by weight are presented in Table 1.

From Table 1 we can see that, in comparison with bulk composition, surface composition for the volcanic samples is considerably lower in $\mathrm{Fe}, \mathrm{Ca}, \mathrm{Mg}$, $\mathrm{Ti}$, and, with the exception of Eyjafjallajökull, in $\mathrm{Na}$ and $\mathrm{K}$. A completely opposite trend $\left(\% \mathrm{Si}_{\text {surface }}>\% \mathrm{Si}_{\text {bulk, }}\right.$, $\% \mathrm{Al}_{\text {surface }}>\% \mathrm{Al}_{\text {bulk }}$ ) is observed for $\mathrm{Si}$ and, with exception of Eyjafjallajökull, for Al. The fact that a higher amount of $\mathrm{Si}$ and $\mathrm{Al}$ is observed on the volcanic particle surface could be due to the fact that minerals in the ash are overlain by a thin glass coating consisting of a random three-dimensional network of tetrahedral units made up of $\mathrm{Si}^{4+}, \mathrm{Al}^{3+}$ and bridging 
oxygen atoms [19]. Leaching of $\mathrm{Na}$ and K elements from the Hagavatn, Mýrdalssandur, Maelifellssandur and Dyngjusandur samples constitutes another plausible explanation for enrichment in \%Si on the surface, especially taking into consideration the fact that the fresh volcanic Eyjafjallajökull sample collected from the plume does not exhibit any difference in the amount of $\mathrm{K}$ and $\mathrm{Na}$ on the surface as compared to the bulk. As for the desert dusts, they show lower \% of surface $\mathrm{Si}$ and Ti composition and higher \% Al composition on the surface than in the bulk ( $\left.\% \mathrm{Si}_{\text {surface }}<\% \mathrm{Si}_{\text {bulk }}, \% \mathrm{Al}_{\text {surface }}>\% \mathrm{Al}_{\text {bulk }}\right)$. The trends for other elements on the surface of desert dusts are less clear. A sharp difference in surface vs bulk composition raises a question of which one would be more important while studying interactions of $\mathrm{SO}_{2}$ gas with the volcanic particles. It was highlighted that surface of the ash can be modified during eruption [6,50]. Due to potential modifications of volcanic particles during eruption and to the fact that $\mathrm{SO}_{2}$ gas is unlikely to penetrate into the solid dust particle, surface composition is expected to define the interfacial interactions [51].

As can be seen from Table 1, composition of desert and volcanic dusts is dominated by silicon ( $\mathrm{Si}$ ) and aluminum ( $\mathrm{Al})$, followed by other elements, such as iron (Fe), calcium $(\mathrm{Ca})$, magnesium $(\mathrm{Mg})$ and $\mathrm{Ti}$ (titanium). With the exception of Si that demonstrated low reactivity, oxides of $\mathrm{Fe}, \mathrm{Ca}, \mathrm{Al}, \mathrm{Mg}$ and $\mathrm{Ti}$ and relatively simple minerals such as calcite $\left(\mathrm{CaCO}_{3}\right)$ and goethite $(\mathrm{FeOOH})$ were used in the literature as proxies to study behavior of natural dusts based on the fact that they are seen as "reactive components" [28].

Specific surface area measurements/The specific surface area (SSA) is a physical property of solids that represents the total surface area of a material per mass unit $\left(\mathrm{m}^{2}\right.$ $\mathrm{g}^{-1}$ ) and is often used for the determination of the kinetic and sorption parameters. To determine SSA, the Brunauer-Emmett-Teller (BET) method was employed. Nitrogen $\left(\mathrm{N}_{2}\right)$ adsorption measurements were performed with a laboratory gas sorption analysis system $[52,53]$ within 0.05 to 0.3 relative pressure range $\left(\mathrm{P} / \mathrm{P}_{0}\right)$ of $\mathrm{N}_{2}$. To determine the range of uncertainty, three adsorption measurements were conducted for each sample. The results of the BET specific surface area $\left(\mathrm{SSA}_{\mathrm{BET}}\right)$ of the samples used in the framework of the current study are displayed in Table 2. Specific surface area was used to calculate the amount of sulfites/sulfate per $\mathrm{m}^{2}$. 


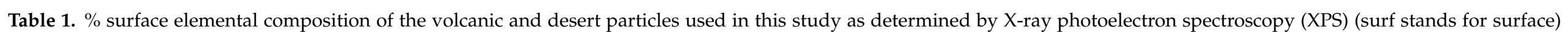

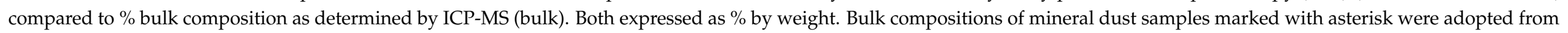
[52]. Error on the XPS measurements $<10 \%$, error on ICP-MS measurements $<10 \%$ for major elements.

\begin{tabular}{|c|c|c|c|c|c|c|c|c|c|c|c|c|c|c|c|c|}
\hline \multirow[t]{2}{*}{ Element } & \multicolumn{2}{|c|}{ Mýrdalssandur } & \multicolumn{2}{|c|}{ Dyngjusandur } & \multicolumn{2}{|c|}{ Hagavatn } & \multicolumn{2}{|c|}{ Maelifellssandur } & \multicolumn{2}{|c|}{ Eyjafjallajökull } & \multicolumn{2}{|c|}{$\begin{array}{c}\text { M'Bour } \\
\text { Saharan Dust }\end{array}$} & \multicolumn{2}{|c|}{ Gobi Dust } & \multicolumn{2}{|c|}{ ATD Dust } \\
\hline & $\begin{array}{r}\text { surf } \\
\text { wt.\% }\end{array}$ & $\begin{array}{l}\text { bulk } \\
\text { wt. } \%\end{array}$ & $\begin{array}{r}\text { surf } \\
\text { wt. } \%\end{array}$ & $\begin{array}{l}\text { bulk } \\
\text { wt. } \%\end{array}$ & $\begin{array}{r}\text { surf } \\
\text { wt. } \%\end{array}$ & $\begin{array}{l}\text { bulk } \\
\text { wt.\% }\end{array}$ & $\begin{array}{r}\text { surf } \\
\text { wt. } \%\end{array}$ & $\begin{array}{l}\text { bulk } \\
\text { wt.\% }\end{array}$ & $\begin{array}{r}\text { surf } \\
\text { wt. } \%\end{array}$ & $\begin{array}{l}\text { bulk } \\
\text { wt.\% }\end{array}$ & $\begin{array}{r}\text { surf } \\
\text { wt.\% }\end{array}$ & $\begin{array}{l}\text { Bulk* } \\
\text { wt. } \%\end{array}$ & $\begin{array}{r}\text { surf } \\
\text { wt.\% }\end{array}$ & $\begin{array}{l}\text { Bulk* } \\
\text { wt. } \%\end{array}$ & $\begin{array}{r}\text { surf } \\
\text { wt. } \%\end{array}$ & $\begin{array}{l}\text { Bulk* } \\
\text { wt. } \%\end{array}$ \\
\hline $\mathrm{Si}$ & 47.1 & 31.3 & 49.0 & 32.7 & 42.8 & 27.5 & 43.7 & 28.3 & 60.0 & 49.5 & 57.0 & 94.4 & 54.7 & 57.6 & 57.5 & 74.6 \\
\hline $\mathrm{Fe}$ & 20.0 & 23.0 & 15.9 & 19.7 & 10.5 & 19.6 & 22.0 & 23.8 & 7.7 & 13.0 & 6.1 & 1.3 & 6.7 & 5.5 & 8.2 & 3.1 \\
\hline $\mathrm{Ca}$ & 8.1 & 13.9 & 9.7 & 16.3 & 9.0 & 19.5 & 6.3 & 14.0 & 5.5 & 7.3 & 2.4 & 1.0 & 7.7 & 16.1 & 5.5 & 4.4 \\
\hline $\mathrm{Mg}$ & 3.3 & 5.1 & 4.8 & 7.3 & 2.4 & 10.4 & 3.0 & 5.7 & 1.5 & 3.3 & 0 & 0.1 & 6.1 & 2.3 & 3.9 & 1.0 \\
\hline $\mathrm{Ti}$ & 3.8 & 7.6 & 2.0 & 3.3 & 1.8 & 2.4 & 4.3 & 6.1 & 1.0 & 2.4 & 0.2 & 0.7 & 0 & 0.8 & 0.5 & 0.5 \\
\hline $\mathrm{Na}$ & 2.3 & 4.8 & 1.0 & 3.9 & 1.4 & 3.1 & 1.3 & 4.6 & 7.5 & 7.3 & 0.3 & 0.2 & 0.8 & 2.5 & 1.3 & 2.5 \\
\hline K & 0.9 & 1.3 & 0 & 0.6 & 0 & 0.2 & 0.4 & 1.5 & 3.3 & 3.1 & 1.9 & 0.1 & 4.7 & 3.5 & 4.4 & 4.0 \\
\hline other & 0 & 0.7 & 0.8 & 0.4 & 0.3 & 0.6 & 0.8 & 0.5 & 0.1 & 0.5 & 0 & 0.1 & 0 & 0.7 & 0.7 & 0.1 \\
\hline
\end{tabular}


Table 2. Brunauer-Emmett-Teller (BET) Specific Surface Area $\left(\mathrm{m}^{2} \mathrm{~g}^{-1}\right)$ of various natural volcanic and desert samples, selected clay minerals and mineral proxies used in the study. Specific surface area (SSA) of the studied samples was determined using the 2-parameter BET method. At least three nitrogen adsorption experiments were conducted for each sample using a homemade gas sorption analyzer. The values presented are the average of the measurements and the quoted errors correspond to one standard deviation. FeOOH data are retrieved from [54].

\begin{tabular}{|c|c|}
\hline Origin of the Icelandic v-Dust Sample & $\begin{array}{l}\text { BET Specific Surface Area } \\
\left(\mathrm{m}^{2} \mathrm{~g}^{-1}\right)\end{array}$ \\
\hline Mýrdalssandur & $1.5 \pm 0.38$ \\
\hline Dyngjusandur & $7.0 \pm 1.8$ \\
\hline Hagavatn & $4.5 \pm 1.1$ \\
\hline Maelifellssandur & $8.2 \pm 2.0$ \\
\hline Eyjafjallajökull & $0.75 \pm 0.19$ \\
\hline \multicolumn{2}{|l|}{ Origin of the Natural Mineral Dust Sample } \\
\hline M'Bour & $14.5 \pm 1.0$ \\
\hline Gobi & $10.5 \pm 2.0$ \\
\hline ATD & $67.2 \pm 1.8$ \\
\hline \multicolumn{2}{|l|}{ Selected Clays } \\
\hline Kaolinite & $9.2 \pm 2.8$ \\
\hline Montmorillonite & $225 \pm 68$ \\
\hline Illite & $22.2 \pm 6.7$ \\
\hline \multicolumn{2}{|l|}{ Selected Mineral Oxides } \\
\hline $\mathrm{SiO}_{2}$ (Silica gel) & $402 \pm 40$ \\
\hline $\mathrm{SiO}_{2}$ (Quartz) & $1.49 \pm 0.12$ \\
\hline $\mathrm{Al}_{2} \mathrm{O}_{3}$ & $118 \pm 22$ \\
\hline $\mathrm{CaO}$ & $66.01 \pm 0.54$ \\
\hline $\mathrm{CaCO}_{3}$ & $0.6 \pm 0.1$ \\
\hline $\mathrm{Fe}_{3} \mathrm{O}_{4}$ & $3.4 \pm 0.4$ \\
\hline $\mathrm{FeOOH}$ & 15.8 \\
\hline $\mathrm{TiO}_{2}$ & $52 \pm 6.4$ \\
\hline $\mathrm{MgO}$ & $49.26 \pm 0.23$ \\
\hline
\end{tabular}

\subsection{Chemicals and Reagents}

HPLC grade acetonitrile (ACN), 99.95\% and methanol (MeOH), 99.9\% were obtained from Biosolve Chimie, Dieuze, France. Potassium hydrogen phthalate and triethanolamine, $99 \%$ of analytical grade were purchased from Acros Organics, Geel, Belgium. Cetylpyridinium chloride, $98 \%$ was purchased from Alfa Aesar, Kander, Germany. Sodium sulfate, $99 \%$ purity was purchased from Merck, Darmstadt, Germany. Sodium sulfite, $>95 \%$ purity was purchased from Fischer Chemical, Loughborough, UK. Formalin ( $37 \%$ formaldehyde solution by weight containing $10-15 \% \mathrm{MeOH}$ as stabilizer) was obtained from SigmaAldrich, Overijse, Belgium. Other chemicals and solvents of analytical grade were used during research. Deionized water (DI) was used throughout the investigation. A certified $\mathrm{SO}_{2}$ cylinder, $250 \mathrm{ppm}$ diluted in synthetic air (nearly $80 \% \mathrm{~N}_{2}$ and $20 \% \mathrm{O}_{2}$ ) was purchased from Messer, France.

\subsection{Preparation of Solutions for HPLC Analysis}

Potassium Hydrogen Phthalate $1.0 \mathrm{mM}$, adjusted to $\mathrm{pH} 6.5$ with $\mathrm{KOH}$ was vacuum filtered. Stock solution of $1 \%$ Formalin was prepared by adding $10 \mathrm{~mL}$ of Formalin in 
a $1000 \mathrm{~mL}$ volumetric flask and diluting to the volume with $10 \%$ Methanol/Water to prevent polymerization. The solution of $1 \%$ Formalin was used to prepare a $1000 \mathrm{ppm}$ stock solution of Potassium Sulfite $\left(\mathrm{KSO}_{3}\right)$ and a 1000 ppm stock solution of Potassium Sulfate $\left(\mathrm{KSO}_{4}\right)$. Other concentrations of Potassium Sulfites and Potassium Sulfates were prepared from its stock solutions through serial dilution with $1 \%$ Formalin. In particular, solutions were serially diluted to obtain $20 \mathrm{ppm}$ and $200 \mathrm{ppm}$ solutions of $\mathrm{K}_{2} \mathrm{SO}_{3}$ and $10 \mathrm{ppm}$ and $100 \mathrm{ppm}$ solutions of $\mathrm{K}_{2} \mathrm{SO}_{4}$ and used as standards.

\subsection{Dust and Mineral Surrogate Ageing. Extraction of Sulfites and Sulfates}

The setup for ageing of samples consists of two parts: (i) the gas mixing line and (ii) the reactor. A schematic representation of the setup is provided in Figure 1, and further information can be found in recent publications of our group [40]. Therefore, only a brief description will be given herein. A sample weighting from 20 to $160 \mathrm{mg}$ is spread on a $47 \mathrm{~mm}$ Whatman filter paper and is placed in a tightly closed reactor. The gas mixture containing $175 \mathrm{ppm} \mathrm{SO}_{2}$ entering the reactor flows through the filter containing the granular sample. All mineral samples were aged under controlled experimental conditions of $175 \mathrm{ppm} \mathrm{SO} \mathrm{S}_{2}$ gas, $30 \% \mathrm{RH}$ for $1 \mathrm{hr}$, at atmospheric pressure using high purity zero air as bath gas (VOCs $<0.1 \mathrm{ppb}, \mathrm{CO}_{2}<10 \mathrm{ppb}$, and $\mathrm{CO}<80 \mathrm{ppb}$, moisture level ca. $2 \mathrm{ppm}$ ). High concentrations of $\mathrm{SO}_{2}$ were used (i) to reduce the experimental time of a long-lasting process, and (ii) to ensure the formation of sulfites and/or sulfates on the surface of mineral samples in detectable quantities even on the surface of less reactive surrogates.

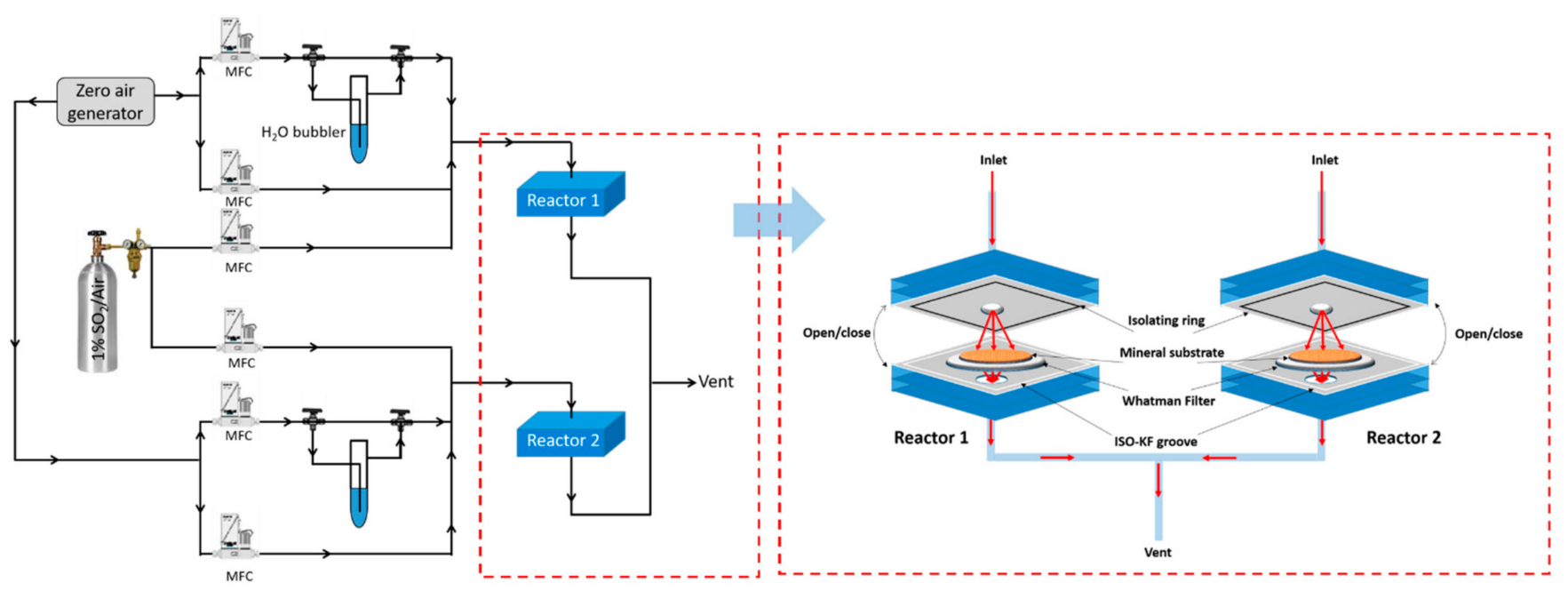

Figure 1. Left: schematic representation of the setup used to age samples of dust with $\mathrm{SO}_{2}$ gas. Right: reactor 1 and 2 with deposited dust, zoomed for clarity.

After $1 \mathrm{~h}$ ageing a sample is weighed, transferred in a $10 \mathrm{~mL}$ glass container and stabilized with $1 \mathrm{~mL}$ of $1 \%$ Formalin followed by $10 \mathrm{~min}$ sonication in the ultrasound bath. The solution is filtered through a $0.45 \mu \mathrm{m}$ pore size $30 \mathrm{~mm}$ diameter filter using a syringe. The remaining dust is washed with $1 \mathrm{~mL}$ of $1 \%$ Formalin and filtered through the same filter that was used to filter the first solution. The final combined solution is analyzed by HPLC system.

\subsection{Instrumentation and Chromatographic Conditions}

A reversed-phase HPLC method developed earlier and validated for system suitability, specificity, robustness, solution stability, linearity and range, precision, limit of detection and limit of quantitation, was used to assay sulfites and sulfates on the surface of dust [40]. Chromatography equipment consisted of Thermo Scientific Dionex UltiMate 3000 UHPLC System with UV/VIS Detector (Thermo Scientific, Waltham, MA, USA). Chromeleon 7.0 Data Acquisition System for LC (Thermo Scientific, Waltham, MA, USA) was used to 
analyze the data. HPLC analysis was performed using Restek Ultra Column C18, $5 \mu \mathrm{m}$, Length $250 \mathrm{~mm}$, I.D. $4.60 \mathrm{~mm}$ dynamically coated with $1.0 \mathrm{mM}$ Cetylpyridinium Chloride in $7 \%$ acetonitrile solution to produce a charged surface as recommended by Zuo et al. [55]. The HPLC instrument was operated isocratically at $23{ }^{\circ} \mathrm{C}$ using Potassium Hydrogen Phthalate Buffer $1.0 \mathrm{mM}$, adjusted to $\mathrm{pH} 6.5$ with a dilute solution of Potassium Hydroxide mobile phase and run at a flow rate of $1.0 \mathrm{~mL} / \mathrm{min}$ with negative UV-Vis detection at $255 \mathrm{~nm}$ for $15 \mathrm{~min}$. The injection volume was $10 \mu \mathrm{L}$. Columns were cleaned at $1 \mathrm{~mL} / \mathrm{min}$ for $30 \mathrm{~min}$ with $\mathrm{ACN} /$ water $(50: 50, v / v), 30 \mathrm{~min}$ with $\mathrm{ACN} /$ water $(75: 25, v / v)$, and $1 \mathrm{~h}$ with $100 \%$ ACN before being coated with $1.0 \mathrm{mM}$ cetylpyridinium chloride in ACN/water (7:93, $v / v)$ at $0.5 \mathrm{~mL} / \mathrm{min}$ for $3 \mathrm{~h}$. Using a calibration curve for sulfites and sulfates determined daily, the system evaluated the concentration of sulfites and sulfates in the extracts of natural samples and proxies. This concentration measured in micrograms per $\mathrm{mL}(\mu \mathrm{g} / \mathrm{mL})$ was converted to micrograms per gram $(\mu \mathrm{g} / \mathrm{g})$ of dust using the mass of the sample. Finally, using the $S S A$ of the samples studied, mass of sulfites/sulfates per gram of dust was converted to mass of sulfites/sulfates per meter squared $\left(\mu \mathrm{g} / \mathrm{m}^{2}\right)$ of the sample.

\section{Results and Discussion}

Several authors investigating desert dust samples use mineral oxides and so-called "reactive components" as proxies for natural samples. In the following study it was decided to directly compare the amount of sulfites/sulfates present on the surface of natural volcanic and desert dusts after $1 \mathrm{~h}$ ageing at $30 \%$ of $\mathrm{RH}$ with $175 \mathrm{ppm}$ of $\mathrm{SO}_{2}$ gas versus sulfites/sulfates present on commonly used surrogates in order to evaluate this approach.

\subsection{First Insights on $\mathrm{SO}_{2}$ Uptake on Mineral Samples}

Figure 2 shows the amounts of sulfites and sulfates quantified on: (i) different metal oxides based on $\mathrm{Al}, \mathrm{Fe}, \mathrm{Ti}, \mathrm{Mg}, \mathrm{Ca}$ and $\mathrm{Si}$ content identified on the surface of desert and volcanic dusts (Table 2), (ii) volcanic and (iii) desert dusts, (iv) clays, (v) goethite and (vi) calcium carbonate. Note that clay minerals, calcium carbonate and goethite are not observed in volcanic ash but they are found in desert dusts and discussed in the literature; thus, they were also included to better explain the behavior of natural samples [56].

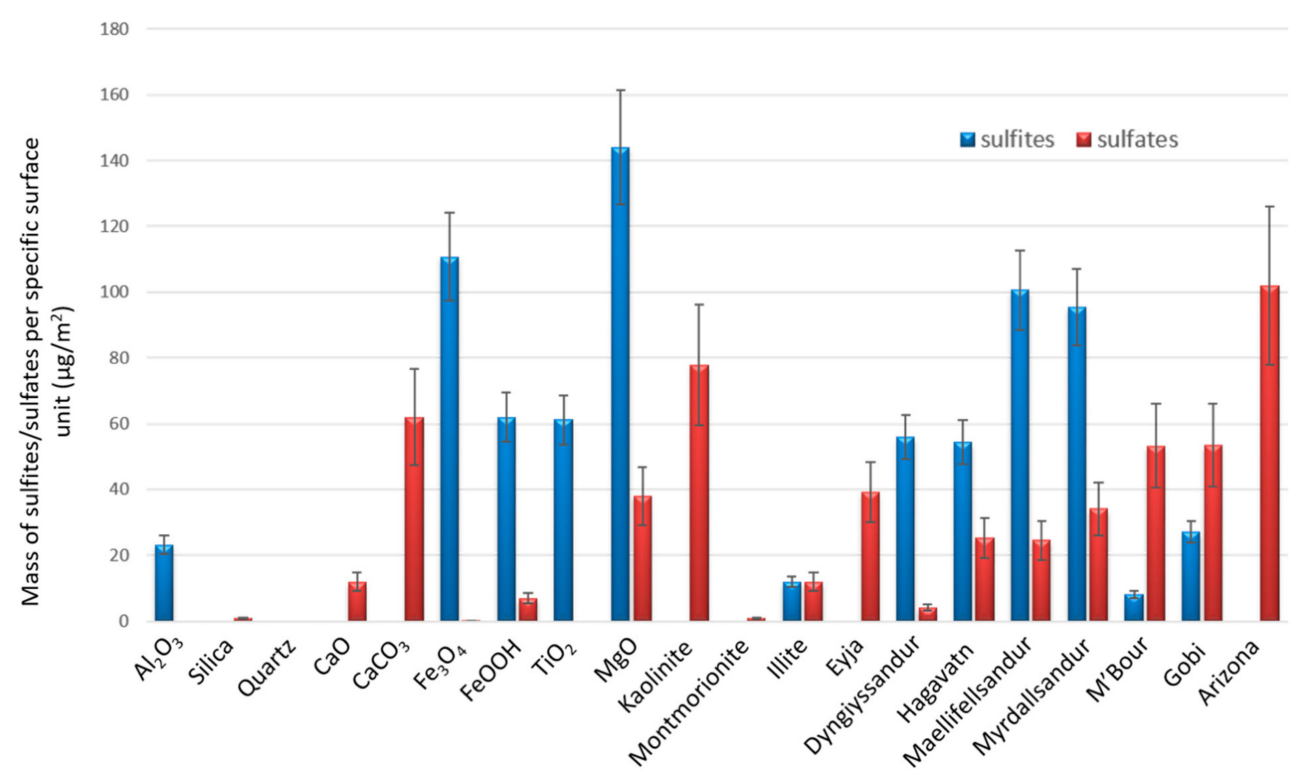

Figure 2. Amounts of sulfites and sulfates quantified on the surface of desert and volcanic samples as compared to the amounts of sulfites and sulfates formed on various pure metal oxides, calcium carbonate, goethite and clay minerals. All samples were exposed to $175 \mathrm{ppm} \mathrm{SO}_{2}$ for $1 \mathrm{~h}$ at $30 \% \mathrm{RH}$. Sulfites and sulfates were extracted with $2 \mathrm{~mL}$ of $1 \%$ Formalin, sonicated for $10 \mathrm{~min}$ and analyzed by HPLC. 
From Figure 2 we can see that on the surface of pure single mineral oxides, with the exception of $\mathrm{MgO}$ (contains both sulfites and sulfates) and $\mathrm{SiO}_{2}$ (sulfites/sulfates are below the detection limits), only one type of sulfur species is observed: either sulfites or sulfates. In particular, on the surface of $\mathrm{Al}_{2} \mathrm{O}_{3}, \mathrm{Fe}_{2} \mathrm{O}_{3}, \mathrm{TiO}_{2}$, sulfites are solely formed, while on the surface of $\mathrm{CaO}, \mathrm{CaCO}_{3}$, only sulfates are observed. Meanwhile, both sulfites and sulfates are detected on the surface of most desert and volcanic samples, except for Eyjafjallajökull and Arizona dust that exhibit only sulfates. As a general trend, on the surface of volcanic samples, with exception of Eyjafjallajökull, we observe a higher amount of sulfites and a lower amount of sulfates than on the surface of desert dusts. In addition, goethite contains both sulfites and sulfates. Three clay minerals show contrasting behavior: sulfites are only observed on the surface of illite, while sulfates are observed for kaolinite and illite, but not for montmorillonite. Apparently, different minerals have different behaviors towards $\mathrm{SO}_{2}$ gas and its further conversion from sulfites to sulfates.

Different distribution of sulfites and sulfates on the surface can be investigated from the "rate of conversion" point of view. Since sulfite formation necessarily precedes sulfate formation, the fact that we observe different sulfite-to-sulfate ratios on different dusts means that conversion of sulfites to sulfates follows a different timeframe [24,39]. Thus, the reactions of $\mathrm{SO}_{2}$ with the surface can be simplified in the following way:

$$
\mathrm{SO}_{2(\mathrm{~g})} \leftrightarrow \mathrm{SO}_{2(\mathrm{ads})} \stackrel{\text { OH group or lattice Oxygen }}{\longrightarrow} \mathrm{SO}_{3}^{2-} \stackrel{\text { OHgroup or adsorbed atomic Oxygen }}{\longrightarrow} \mathrm{SO}_{4}^{2-}
$$

Apparently, the rate of sulfate formation is higher for desert dusts in comparison with volcanic dusts. It suggests that at least a part of the surface of desert dusts has a high sulfiteto-sulfate conversion rate and that at least a part of the surface of volcanic particles has a lower reaction rate. The fact that no sulfites are observed on the surface of certain mineral oxides and natural samples by no means implies that they are not formed. If the sulfates are observed it follows that sulfites are formed as well but that their rate of consumption is too fast to be observed by our method [39]. On the other hand, absence of sulfates on the surface means that they were not formed (or they are formed in concentrations below the detection limit) due to extremely slow rate of sulfite-to-sulfate conversion on the corresponding surface.

3.2. Classification of Mineral Samples Based on Their Efficiency to Form Sulfites and/or Sulfates. Can a Natural Dust be Represented by One Chosen Individual Component?

Based on Figure 2, mineral dusts and metal oxides can be grouped in the following way (Table 3). Group 1 forms neither sulfites nor sulfates on the surface (at least at concentrations above the detection limits): silica $\left(\mathrm{SiO}_{2}\right)$, quartz $\left(\mathrm{SiO}_{2}\right)$ and montmorillonite. Group 2 has only sulfites and fails to convert them to sulfates: $\mathrm{Al}_{2} \mathrm{O}_{3}, \mathrm{Fe}_{3} \mathrm{O}_{4}$, and $\mathrm{TiO}_{2}$. Group 3 exhibits both sulfites and sulfates: FeOOH, $\mathrm{MgO}$, illite, Dyngjusandur, Hagavatn, Mýrdalssandur, Maelifellssandur, Gobi and M'Bour. Finally, Group 4 converts sulfites to sulfates so fast that no sulfites are observed: $\mathrm{CaO}, \mathrm{CaCO}_{3}$, Eyjafjallajökull, kaolinite and Arizona Test Dust. 
Table 3. Classification of mineral samples based on their ability to form sulfites and/or sulfates on their surfaces.

\begin{tabular}{|c|c|c|}
\hline Group & Samples & Comments \\
\hline 1 & $\begin{array}{l}\text { Silica gel }\left(\mathrm{SiO}_{2}\right) \text { quartz }\left(\mathrm{SiO}_{2}\right), \\
\text { montmorillonite }\end{array}$ & $\begin{array}{l}\text { Sulfites and sulfates formation are } \\
\text { below detection limits. }\end{array}$ \\
\hline 2 & $\mathrm{Al}_{2} \mathrm{O}_{3}, \mathrm{Fe}_{3} \mathrm{O}_{4}$, and $\mathrm{TiO}_{2}$ & Only sulfites are detected. \\
\hline 3 & $\begin{array}{l}\text { FeOOH, MgO, illite, Dyngjusandur, } \\
\text { Hagavatn, Mýrdalssandur, } \\
\text { Maelifellssandur, Gobi and M’Bour }\end{array}$ & $\begin{array}{l}\text { Both sulfites and sulfates } \\
\text { are detected. }\end{array}$ \\
\hline 4 & $\begin{array}{c}\mathrm{CaO}, \mathrm{CaCO}_{3} \text {, Eyjafjallajökull, } \\
\text { kaolinite and Arizona Test Dust }\end{array}$ & $\begin{array}{l}\text { Detection of sulfates only. Fast } \\
\text { conversion of sulfites to sulfates } \\
\text { prevents their detection. }\end{array}$ \\
\hline
\end{tabular}

As we can see, not one surrogate is able to completely represent formation of sulfites and sulfates on the surface of all the dusts, as dusts themselves differ in the amount and distribution of sulfur species. Especially bad candidates for proxies would be Group 1 and 2 oxides, as they either form no sulfur species or demonstrate an extremely low rate of sulfite-to-sulfate conversion. Moreover, we can clearly see that $\mathrm{Al}_{2} \mathrm{O}_{3}$ and $\mathrm{CaCO}_{3}$, which are often chosen as proxies based on the assumption that each is considered to be "the most important reactive component of mineral dust", show highly contrasted behaviors: only sulfites are formed on $\mathrm{Al}_{2} \mathrm{O}_{3}$ while only sulfates are observed on $\mathrm{CaCO}_{3}[29,30]$. Likewise, Huang et al. saw a 10-times decrease in the total amount of sulfur species formed on the surface of alumina vs Asian Mineral Dust particles collected in Beijing [30]. Those discrepancies could at least in part be explained by using alumina as a proxy. In addition, with exception of $\mathrm{SiO}_{2}$, all other proxy candidates exhibit significant reactivity towards formation of sulfites/sulfates, and thus choosing only one component while ignoring all the others does not seem justified (Figure 2). A conclusion can be made that no individual oxide can relevantly represent the reactivity of a complex heterogeneous mixture. But can reactivity of a mixture be investigated as a sum of reactivities of individual contributors, keeping in mind that these individual contributors are not necessarily present in the natural mixture in the assigned oxide form? Next, we will try to deduce individual contribution of pure oxides, goethite and calcium carbonate surrogates in the formation of sulfites/sulfates on natural samples.

\subsection{Can a Natural Dust be Characterized by a Sum of "Representative" Simple Mineral Proxies?}

Zhang et al. compared the reactivities of different oxides together with their mixture (based on the abundance of the corresponding elements in the continental crust), taking into consideration their specific area, and placed them in the following order: $\mathrm{Fe}_{2} \mathrm{O}_{3}>\mathrm{MgO}$ $>\mathrm{TiO}_{2}>\mathrm{FeOOH}>$ mixture $>\mathrm{Al}_{2} \mathrm{O}_{3}>\mathrm{SiO}_{2}$ [23]. These authors came to the conclusion that the reactivity of the mixture, which was obtained by mixing the different oxides based on their abundances in the continental crust, was measured to be twice its theoretical value, which demonstrates a synergistic effect [23]. Contrary to the results obtained by Zhang et al., reactivity of China Loess was successfully predicted from the reactivity of its single component oxides and carbonates [28]. Following the same logic we decided to test whether the amount of sulfites and sulfates formed on the surface of a natural dust can be predicted from the sum of relative contributions of its individual oxides without accounting for $\mathrm{K}$ and Na component. Note that to take into account the well-known discrepancies between bulk and surface composition, the surface composition for dusts expressed as wt.\% of each oxide was calculated from the wt.\% surface elemental composition measured with XPS. This approach was tested by calculating the theoretical amount of sulfites/sulfates 
expected on the sample surface $S_{\text {sample }}^{\text {theoretical }}\left(\mu \mathrm{g} / \mathrm{m}^{2}\right)$ based on our experimental results for simple oxides using the following equation:

$$
S_{\text {sample }}^{\text {theoretical }}=\sum_{i} f_{i} S_{i}
$$

where $f_{i}$ is the fraction of $i^{\text {th }}$ component and $S_{i}\left(\mu \mathrm{g} / \mathrm{m}^{2}\right)$ is the amount of sulfur species measured on the surface of $i^{\text {th }}$ component. The calculated amount of sulfites and sulfates was then compared to the experimentally measured results on natural volcanic/desert samples.

From Table 4 it can be observed that the calculated and measured values are very different. Theoretical amounts of sulfates are up to 50 times lower than the experimentally measured ones. Indeed, for sulfates, theoretical values range from 1 to $4 \mu \mathrm{g} / \mathrm{m}^{2}$ while the experimental values range from 4 to $100 \mu \mathrm{g} / \mathrm{m}^{2}$. As for sulfites, the theoretical values range from 2 to $20 \mu \mathrm{g} / \mathrm{m}^{2}$ while the experimental values range from 0 to $100 \mu \mathrm{g} / \mathrm{m}^{2}$. The reason of the mismatch is most probably related to the fact that: (i) mineralogical surface composition of proxies is not the same as the one of real natural samples and (ii) there is a synergetic effect of the mixture of components of natural samples on the transformation of $\mathrm{SO}_{2}$ to sulfites/sulfates, which cannot be reproduced by using proxies. Thus, substituting a complex mineral for a collection of simple oxides does not seem to be appropriate for $\mathrm{SO}_{2}$ transformation. For example, silicate enstatite with molecular formula $\mathrm{MgSiO}_{3}$ reported as $60 \% \mathrm{SiO}_{2}$ and $40 \% \mathrm{MgO}$ cannot be investigated as a mixture of these two simple oxides. If that is the case it explains why kaolinite clay, which in terms of oxides is sometimes represented as $\mathrm{Al}_{2} \mathrm{O}_{3} \cdot 2 \mathrm{SiO} \cdot 2 \mathrm{H}_{2} \mathrm{O}$, does not at all behave as $\mathrm{Al}_{2} \mathrm{O}_{3}$ (no sulfites observed on kaolinite, while only sulfites are observed on $\mathrm{Al}_{2} \mathrm{O}_{3}$ ) or as quartz (a negligible amount of sulfate is observed on quartz, while a high amount is present on kaolinite) (Figure 2).

A better approach to approximate the behavior of a complex mixture is to identify and quantify the amount of minerals present in a selected dust and directly compare individual mineral phases to the behavior of the heterogeneous mixture. Thus, sulfites on the surface of desert dusts can be compared to those detected on pure hematite $\left(\mathrm{Fe}_{2} \mathrm{O}_{3}\right)$, goethite $(\mathrm{FeOOH})$, magnesium oxide $(\mathrm{MgO})$, rutile $\left(\mathrm{TiO}_{2}\right)$, aluminum oxide $\left(\mathrm{Al}_{2} \mathrm{O}_{3}\right)$, carbonates $\left(\mathrm{CaCO}_{3}\right)$, plagioclase $\left(\mathrm{NaAlSi}_{3} \mathrm{O}_{8}\right)$, muscovite $\left(\mathrm{KAl}_{3} \mathrm{Si}_{3} \mathrm{O}_{10}(\mathrm{OH})_{2}\right)$, kaolinite $\left(\mathrm{Al}_{2} \mathrm{Si}_{2} \mathrm{O}_{5}(\mathrm{OH})_{4}\right)$, pyrope $\left(\mathrm{Mg}_{3} \mathrm{Al}_{2}\left(\mathrm{SiO}_{4}\right)_{3}\right)$, talc $\left(\mathrm{Mg}_{3} \mathrm{Si}_{4} \mathrm{O}_{10}(\mathrm{OH})_{2}\right)$, and so on, while plagioclase $\left(\mathrm{NaAlSi}_{3} \mathrm{O}_{8}-\right.$ $\left.\mathrm{CaAl}_{2} \mathrm{Si}_{2} \mathrm{O}_{8}\right)$, pyroxene $\left((\mathrm{Ca}, \mathrm{Na})(\mathrm{Mg}, \mathrm{Fe}, \mathrm{Al}, \mathrm{Ti})(\mathrm{Si}, \mathrm{Al})_{2} \mathrm{O}_{6}\right)$, olivine $\left((\mathrm{Mg}, \mathrm{Fe})_{2}\left[\mathrm{SiO}_{4}\right]\right)$, magnetite $\left(\mathrm{Fe}_{3} \mathrm{O}_{4}\right)$, ilmenite $\left(\mathrm{FeTiO}_{3}\right)$ and aluminosilicate glasses would be more appropriate minerals to consider in the case of volcanic particles. As for sulfates, the presence of kaolinite $\left(\mathrm{Al}_{2} \mathrm{Si}_{2} \mathrm{O}_{5}(\mathrm{OH})_{4}\right)$ and calcium carbonite $\left(\mathrm{CaCO}_{3}\right)$ can explain a higher amount of sulfates on the surface of Gobi and M'Bour dusts. The exact quantities of minerals are necessary in order to evaluate trends in formation. But mineralogical analysis of dusts and its accurate quantification is laborious and expensive. In addition, certain mineral phases are present in dusts in very small amounts and are not readily obtained in their pure form. A way to bridge the gap between real samples and simple oxide proxies could be to introduce a higher level of complexity to the experimental system working with surrogates, such as to use single mineralogical components of the real dust samples and study them in relation to single oxides. For example, in a study of iron dissolution and specialization in atmospheric mineral dust, it was noted that iron dissolution depends on the amount of $\mathrm{Ti}$ in the natural sample $[57,58]$. To test the hypothesis, an oxide of titanium was added to hematite, an abundant single oxide component of natural dust, and the increase in iron dissolution was observed for both dark and light conditions, while mixing hematite with $\mathrm{Al}_{2} \mathrm{O}_{3}$ or $\mathrm{CaO}$ diminished its iron dissolution [57]. Studies such as this shed light into mechanistic details of the possible synergetic relationships [59]. In line with the findings of the current article, the authors caution that under real atmospheric conditions Ti is present in various mineralogical forms and the mechanistic pathways might be different from those suggested [59]. Thus, an optimum approach would be to use natural dusts to obtain the accurate global trends of their heterogeneous interactions with gases and then to study the proposed mechanisms closer using carefully adapted proxies. 


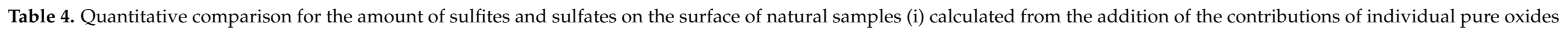

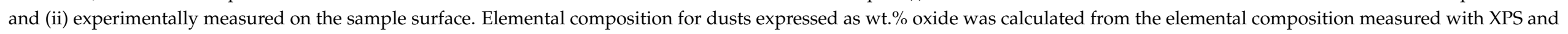
discussed earlier (see Section 2.2, Table 1).

\begin{tabular}{|c|c|c|c|c|c|c|c|c|c|c|c|c|}
\hline $\begin{array}{c}\text { Dust } \\
\text { Sample }\end{array}$ & & $\mathrm{SiO}_{2}$ & $\mathrm{Al}_{2} \mathrm{O}_{3}$ & $\mathrm{CaO}$ & $\mathrm{Na}_{2} \mathrm{O}$ & $\mathrm{MgO}$ & $\mathrm{TiO}_{2}$ & $\mathrm{~K}_{2} \mathrm{O}$ & $\mathrm{Fe}_{2} \mathrm{O}_{3}$ & $\mathrm{MnO}$ & $\begin{array}{l}\text { Calculated from } \\
\text { Individual } \\
\text { Contributions of } \\
\text { Pure Oxides } \\
\text { (S } S_{\text {dust }}^{\text {theoretical })}\end{array}$ & $\begin{array}{c}\text { Experimentally } \\
\text { Measured } \\
\left(S_{d u s t}^{\text {experimental }}\right)\end{array}$ \\
\hline \multirow[b]{2}{*}{ Myrdalssandur } & wt. $\%$ & 59.96 & 17.61 & 4.89 & 2.36 & 3.86 & 2.27 & 0.47 & 8.59 & 0 & & \\
\hline & $\begin{array}{l}\text { Sulfites } \\
\left(\mu \mathrm{g} / \mathrm{m}^{2}\right)\end{array}$ & 0 & 23 & 0 & & 144 & 61 & & 111 & & 20.5 & 95 \\
\hline \multirow{3}{*}{ Dyngjusandur } & wt. $\%$ & 60.14 & 19.67 & 5.68 & 0.95 & 5.56 & 1.18 & 0.00 & 6.59 & 0.23 & & \\
\hline & $\begin{array}{l}\text { Sulfites } \\
\left(\mu \mathrm{g} / \mathrm{m}^{2}\right)\end{array}$ & 0 & 23 & 0 & & 144 & 61 & & 111 & & 20.6 & 56 \\
\hline & $\begin{array}{l}\text { Sulfates } \\
\left(\mu \mathrm{g} / \mathrm{m}^{2}\right)\end{array}$ & 1 & 0 & 12 & & 38 & 0 & & 0 & & 3.4 & 4 \\
\hline \multirow{2}{*}{ Hagavatn } & wt. $\%$ & 50.24 & 35.50 & 5.03 & 1.35 & 2.65 & 1.00 & 0.00 & 4.14 & 0.08 & & \\
\hline & $\begin{array}{l}\text { Sulfates } \\
\left(\mu \mathrm{g} / \mathrm{m}^{2}\right)\end{array}$ & 1 & 0 & 12 & & 38 & 0 & & 0 & & 2.1 & 25 \\
\hline \multirow{3}{*}{ Maelifellsandur } & wt.\% & 56.23 & 22.34 & 3.86 & 1.33 & 3.59 & 2.63 & 0.24 & 9.53 & 0.25 & & \\
\hline & $\begin{array}{l}\text { Sulfites } \\
\left(\mu \mathrm{g} / \mathrm{m}^{2}\right)\end{array}$ & 0 & 23 & 0 & & 144 & 61 & & 111 & & 22.5 & 101 \\
\hline & $\begin{array}{l}\text { Sulfates } \\
\left(\mu \mathrm{g} / \mathrm{m}^{2}\right)\end{array}$ & 1 & 0 & 12 & & 38 & 0 & & 0 & & 2.4 & 24 \\
\hline
\end{tabular}


Table 4. Cont

\begin{tabular}{|c|c|c|c|c|c|c|c|c|c|c|c|c|}
\hline $\begin{array}{c}\text { Dust } \\
\text { Sample }\end{array}$ & & $\mathrm{SiO}_{2}$ & $\mathrm{Al}_{2} \mathrm{O}_{3}$ & $\mathrm{CaO}$ & $\mathrm{Na}_{2} \mathrm{O}$ & $\mathrm{MgO}$ & $\mathrm{TiO}_{2}$ & $\mathrm{~K}_{2} \mathrm{O}$ & $\mathrm{Fe}_{2} \mathrm{O}_{3}$ & $\mathrm{MnO}$ & $\begin{array}{l}\text { Calculated from } \\
\text { Individual } \\
\text { Contributions of } \\
\text { Pure Oxides } \\
\left(S_{\text {dust }}^{\text {theoretical}}\right)\end{array}$ & $\begin{array}{c}\text { Experimentally } \\
\text { Measured } \\
\left(S_{\text {dust }}^{\text {experimental }}\right)\end{array}$ \\
\hline \multirow[b]{2}{*}{ Eyjafjallajokull } & wt. $\%$ & 68.76 & 14.63 & 3.00 & 6.88 & 1.64 & 0.55 & 1.59 & 2.96 & 0.00 & & \\
\hline & $\begin{array}{l}\text { Sulfites } \\
\left(\mu \mathrm{g} / \mathrm{m}^{2}\right)\end{array}$ & 0 & 23 & 0 & & 144 & 61 & & 111 & & 9.3 & 0 \\
\hline \multirow{3}{*}{ Gobi } & wt. $\%$ & 63.03 & 20.30 & 4.22 & 0.76 & 6.56 & 0.00 & 2.27 & 2.60 & 0.24 & & \\
\hline & $\begin{array}{l}\text { Sulfites } \\
\left(\mu \mathrm{g} / \mathrm{m}^{2}\right)\end{array}$ & 0 & 23 & 0 & & 144 & 61 & & 111 & & 17.0 & 27 \\
\hline & $\begin{array}{l}\text { Sulfates } \\
\left(\mu \mathrm{g} / \mathrm{m}^{2}\right)\end{array}$ & 1 & 0 & 12 & & 38 & 0 & & 0 & & 3.6 & 53 \\
\hline \multirow{2}{*}{ M'Bour } & wt. $\%$ & 62.01 & 33.27 & 1.26 & 0.24 & 0.00 & 0.12 & 0.87 & 2.24 & 0.00 & & \\
\hline & $\begin{array}{l}\text { Sulfates } \\
\left(\mu \mathrm{g} / \mathrm{m}^{2}\right)\end{array}$ & 1 & 0 & 12 & & 38 & 0 & & 0 & & 0.8 & 53 \\
\hline \multirow{3}{*}{ ATD } & wt. $\%$ & 66.10 & 19.77 & 2.98 & 1.20 & 4.12 & 0.30 & 2.14 & 3.19 & 0.23 & & \\
\hline & $\begin{array}{l}\text { Sulfites } \\
\left(\mu \mathrm{g} / \mathrm{m}^{2}\right)\end{array}$ & 0 & 23 & 0 & & 144 & 61 & & 111 & & 14.2 & 0 \\
\hline & $\begin{array}{l}\text { Sulfates } \\
\left(\mu \mathrm{g} / \mathrm{m}^{2}\right)\end{array}$ & 1 & 0 & 12 & & 38 & 0 & & 0 & & 2.6 & 102 \\
\hline
\end{tabular}




\section{Conclusions}

In this study, three natural desert and five volcanic samples were compared to a number of extensively used mineral surrogates in their ability to form sulfites and sulfates on their surfaces in order to see if metal oxides, calcium carbonates and goethite could be used as relevant proxies to evaluate the reactivity of natural samples. Based on the same ageing procedure by $\mathrm{SO}_{2}$ gas combined with subsequent extraction and quantification of sulfites and sulfates for all selected samples, it is evidenced that no single proxy used in this study mimics the behavior of natural mineral dust. Due to the complex crystalline structure of different mineral phases, approximation of natural samples using a mixture of simple proxies also does not satisfyingly reflect the behavior of natural samples.

The fact that proxy oxides do not depict the behavior of natural samples to a certain degree questions the representativeness of using surrogates to predict the heterogeneous behavior of natural samples in the atmosphere. It is evidenced that the behavior of $\mathrm{SO}_{2}$ on the surface of $\mathrm{Al}_{2} \mathrm{O}_{3}, \mathrm{Fe}_{3} \mathrm{O}_{4}$ or $\mathrm{TiO}_{2}$ is not the same as on the surface of desert dusts while metals of these oxides are present in the dusts. Desert dusts effectively convert $\mathrm{SO}_{2}$ into sulfates, while $\mathrm{Al}_{2} \mathrm{O}_{3}, \mathrm{Fe}_{3} \mathrm{O}_{4}$ and $\mathrm{TiO}_{2}$ seem to have an extremely slow rate of conversion. In the complex atmospheric reaction pathways, stabilizing a molecule in sulfite form could offer reactivity towards compounds in respect to which sulfates are immune. Since the dusts can behave differently regarding the pollutants, estimations proposed in the literature on the lifetime of pollutants using proxies cannot be assumed without prior proof of the suitability of the proxy in question. To sum up, trying to evaluate the impact of natural dusts on the climate using mostly surrogates, individually or in their mixtures, is problematic as this experimental approach assumes that a proxy and a real natural mineral dust have similar properties, such as particle size, chemical composition, morphology, hygroscopicity, photo activity, and so on, while they clearly do not. This is not to say that studies using surrogates are not valuable; on the contrary, they provide important mechanistic details on various heterogeneous interactions and supply robust kinetic and thermodynamic data. The inherent limitations of using surrogates lies in their relevancy, and it should be proven before making far-reaching conclusions about their role in atmospheric chemistry. Therefore, we highlight the need to evaluate the real-life impact of natural dust on atmospheric processes by working directly with natural samples. It requires facing the diversity of natural mineral aerosols, but it allows addressing the effective atmospheric impact of desert and volcanic dusts. In addition, studies using natural samples can improve proxy-based investigations by allowing a more robust selection of the latter, thus narrowing the gap between proxy-based and natural dust investigations.

Author Contributions: Conceptualization, D.U., M.N.R., and F.T.; Methodology, D.U.; Software, D.U. and M.N.R.; Validation, M.N.R. and F.T.; Formal analysis, D.U.; Investigation, D.U.; Resources, D.U., M.N.R. and F.T.; Data curation, D.U.; Writing-Review \& Editing, D.U., M.N.R., and F.T.; Visualization, D.U., M.N.R.; Supervision, M.N.R. and F.T.; Project Administration, M.N.R. and F.T.; Funding Acquisition, M.N.R. and F.T. All authors have read and agreed to the published version of the manuscript.

Funding: This work was achieved in the frame of Labex CaPPA, funded by ANR through the PIA under contract ANR-11-LABX-0005-01, and CPER CLIMIBIO project, both funded by the Hauts-deFrance Regional Council and the European Regional Development Fund (ERDF).

Institutional Review Board Statement: Not applicable.

Informed Consent Statement: Not applicable.

Data Availability Statement: Not applicable.

Acknowledgments: This work was supported by the French national program LEFE/INSU within the framework of INVOC-dust project. Darya Urupina acknowledges IMT Lille Douai for funding her $\mathrm{PhD}$.

Conflicts of Interest: The authors declare no conflict of interest. 


\section{References}

1. Usher, C.R.; Michel, A.E.; Grassian, V.H. Reactions on mineral dust. Chem. Rev. 2003, 103, 4883-4940. [CrossRef]

2. Bristow, C.S.; Hudson-Edwards, K.A.; Chappell, A. Fertilizing the Amazon and equatorial Atlantic with West African dust. Geophys. Res. Lett. 2010, 37. [CrossRef]

3. Andreae, M.O. Climatic effects of changing atmospheric aerosol levels. In World Survey of Climatology; Elsevier: Amsterdam, The Netherlands, 1995; Volume 16, pp. 347-398.

4. Rose, W.I.; Wunderman, R.L.; Hoffman, M.F.; Gale, L. A volcanologist's review of atmospheric hazards of volcanic activity: Fuego and Mount St. Helens. J. Volcanol. Geotherm. Res. 1983, 17, 133-157. [CrossRef]

5. McCormick, M.P.; Thomason, L.W.; Trepte, C.R. Atmospheric effects of the Mt Pinatubo eruption. Nat. Cell Biol. 1995, 373, 399-404. [CrossRef]

6. Langmann, B. Volcanic Ash versus Mineral Dust: Atmospheric Processing and Environmental and Climate Impacts. Available online: https:/ / www.hindawi.com/journals/isrn/2013/245076/ (accessed on 11 April 2018).

7. Prata, A.J.; Carn, S.A.; Stohl, A.; Kerkmann, J. Long range transport and fate of a stratospheric volcanic cloud from Soufrière Hills volcano, Montserrat. Atmos. Chem. Phys. Discuss. 2007, 7, 5093-5103. [CrossRef]

8. Bagheri, G.; Rossi, E.; Biass, S.; Bonadonna, C. Timing and nature of volcanic particle clusters based on field and numerical investigations. J. Volcanol. Geotherm. Res. 2016, 327, 520-530. [CrossRef]

9. Schepanski, K. Transport of mineral dust and its impact on climate. Geosciences 2018, 8, 151. [CrossRef]

10. Maters, E.C.; Cimarelli, C.; Casas, A.S.; Dingwell, D.B.; Murray, B.J. Volcanic ash ice-nucleating activity can be enhanced or depressed by ash-gas interaction in the eruption plume. Earth Planet. Sci. Lett. 2020, 551, 116587. [CrossRef]

11. Maters, E.C.; Dingwell, D.B.; Cimarelli, C.; Müller, D.; Whale, T.F.; Murray, B.J. The importance of crystalline phases in ice nucleation by volcanic ash. Atmospheric Chem. Phys. Discuss. 2019, 19, 5451-5465. [CrossRef]

12. Li, L.; Chen, Z.M.; Zhang, Y.H.; Zhu, T.; Li, J.L.; Ding, J. Kinetics and mechanism of heterogeneous oxidation of sulfur dioxide by ozone on surface of calcium carbonate. Atmospheric Chem. Phys. Discuss. 2006, 6, 2453-2464. [CrossRef]

13. Ayris, P.M.; Delmelle, P.; Cimarelli, C.; Maters, E.C.; Suzuki, Y.J.; Dingwell, D.B. HCl uptake by volcanic ash in the high temperature eruption plume: Mechanistic insights. Geochim. et Cosmochim. Acta 2014, 144, 188-201. [CrossRef]

14. Casas, A.S.; Wadsworth, F.B.; Ayris, P.M.; Delmelle, P.; Vasseur, J.; Cimarelli, C.; Dingwell, D.B. SO 2 scrubbing during percolation through rhyolitic volcanic domes. Geochim. Cosmochim. Acta 2019, 257, 150-162. [CrossRef]

15. Van Eaton, A.R.; Harper, M.A.; Wilson, C.J.N. High-flying diatoms: Widespread dispersal of microorganisms in an explosive volcanic eruption. Geology 2013, 41, 1187-1190. [CrossRef]

16. Durant, A.J.; Bonadonna, C.; Horwell, C.J. Atmospheric and environmental impacts of volcanic particulates. Elements 2010, 6, 235-240. [CrossRef]

17. Witt, V.; Ayris, P.M.; Damby, D.E.; Cimarelli, C.; Kueppers, U.; Dingwell, D.B.; Wörheide, G. Volcanic ash supports a diverse bacterial community in a marine mesocosm. Geobiology 2017, 15, 453-463. [CrossRef]

18. Vodyanitskii, Y.N. Elements oxides as a source of errors in the gross chemical composition of soil and ways to eliminate the errors. Ann. Agrar. Sci. 2018, 16, 90-93. [CrossRef]

19. Delmelle, P.; Wadsworth, F.B.; Maters, E.C.; Ayris, P.M. High temperature reactions between gases and ash particles in volcanic eruption plumes. Rev. Miner. Geochem. 2018, 84, 285-308. [CrossRef]

20. Dagsson-Waldhauserova, P.; Arnalds, O.; Olafsson, H.; Hladil, J.; Skala, R.; Navratil, T.; Chadimova, L.; Meinander, O. Snow-Dust Storm: Unique case study from Iceland, March 6-7, 2013. Aeolian Res. 2015, 16, 69-74. [CrossRef]

21. Crowley, J.N.; Ammann, M.; Cox, R.A.; Hynes, R.G.; Jenkin, M.E.; Mellouki, A.; Rossi, M.J.; Troe, J.; Wallington, T.J. Evaluated kinetic and photochemical data for atmospheric chemistry: Volume V-heterogeneous reactions on solid substrates. Atmospheric Chem. Phys. Discuss. 2010, 10, 9059-9223. [CrossRef]

22. Goodman, A.L.; Li, P.; Usher, C.R.; Grassian, V.H. Heterogeneous uptake of sulfur dioxide on aluminum and magnesium oxide particles. J. Phys. Chem. A 2001, 105, 6109-6120. [CrossRef]

23. Zhang, X.; Zhuang, G.; Chen, J.; Wang, Y.; Wang, X.; An, Z.; Zhang, P. Heterogeneous reactions of sulfur dioxide on typical mineral particles. J. Phys. Chem. B 2006, 110, 12588-12596. [CrossRef]

24. Wang, T.; Liu, Y.; Deng, Y.; Fu, H.; Zhang, L.; Chen, J. Emerging investigator series: Heterogeneous reactions of sulfur dioxide on mineral dust nanoparticles: From single component to mixed components. Environ. Sci. Nano 2018, 5, 1821-1833. [CrossRef]

25. Wang, T.; Liu, Y.; Deng, Y.; Fu, H.; Zhang, L.; Chen, J. Adsorption of $\mathrm{SO}_{2}$ on mineral dust particles influenced by atmospheric moisture. Atmos. Environ. 2018, 191, 153-161. [CrossRef]

26. Nanayakkara, C.E.; Pettibone, J.; Grassian, V.H. Sulfur dioxide adsorption and photooxidation on isotopically-labeled titanium dioxide nanoparticle surfaces: Roles of surface hydroxyl groups and adsorbed water in the formation and stability of adsorbed sulfite and sulfate. Phys. Chem. Chem. Phys. 2012, 14, 6957-6966. [CrossRef]

27. Wu, L.Y.; Tong, S.R.; Wang, W.G.; Ge, M.F. Effects of temperature on the heterogeneous oxidation of sulfur dioxide by ozone on calcium carbonate. Atmospheric Chem. Phys. Discuss. 2011, 11, 6593-6605. [CrossRef]

28. Usher, C.R.; Al-Hosney, H.; Carlos-Cuellar, S.; Grassian, V.H. A laboratory study of the heterogeneous uptake and oxidation of sulfur dioxide on mineral dust particles. J. Geophys. Res. Space Phys. 2002, 107, ACH 16-1-ACH 16-9. [CrossRef] 
29. Zhang, Y.; Tong, S.; Ge, M.; Jing, B.; Hou, S.; Tan, F.; Chen, Y.; Guo, Y.; Wu, L. The influence of relative humidity on the heterogeneous oxidation of sulfur dioxide by ozone on calcium carbonate particles. Sci. Total. Environ. 2018, 633, 1253-1262. [CrossRef] [PubMed]

30. Huang, L.; Zhao, Y.; Li, H.; Chen, Z. Hydrogen peroxide maintains the heterogeneous reaction of sulfur dioxide on mineral dust proxy particles. Atmos. Environ. 2016, 141, 552-559. [CrossRef]

31. Bluth, G.J.S.; Schnetzler, C.C.; Krueger, A.J.; Walter, L.S. The contribution of explosive volcanism to global atmospheric sulphur dioxide concentrations. Nat. Cell Biol. 1993, 366, 327-329. [CrossRef]

32. Highwood, E.-J.; Stevenson, D.S. Atmospheric impact of the 1783-1784 Laki Eruption: Part II Climatic effect of sulphate aerosol. Atmos. Chem. Phys. Discuss. 2003, 3, 1177-1189. [CrossRef]

33. Daniel, J.J. Introduction to Atmospheric Chemistry; Princeton University Press: Princeton, NJ, USA, 1999; ISBN 978-1-4008-4154-7.

34. Finlayson-Pitts, B.J.; Pitts, J.N., Jr. Chemistry of the Upper and Lower Atmosphere: Theory, Experiments, and Applications; Elsevier: Amsterdam, The Netherlands, 1999; ISBN 978-0-08-052907-3.

35. Schmidt, A.; Ostro, B.; Carslaw, K.S.; Wilson, M.; Thordarson, T.; Mann, G.W.; Simmons, A.J. Excess mortality in Europe following a future Laki-style Icelandic eruption. Proc. Natl. Acad. Sci. USA 2011, 108, 15710-15715. [CrossRef] [PubMed]

36. US EPA. O. Sulfur Dioxide Basics. Available online: https://www.epa.gov/so2-pollution/sulfur-dioxide-basics (accessed on 14 August 2020).

37. Stevenson, D.S.; Johnson, C.E.; Highwood, E.J.; Gauci, V.; Collins, W.J.; Derwent, R.G. Atmospheric impact of the 1783-1784 Laki eruption: Part I Chemistry modelling. Atmos. Chem. Phys. Discuss. 2003, 3, 487-507. [CrossRef]

38. Baltrusaitis, J.; Cwiertny, D.M.; Grassian, V.H. Adsorption of sulfur dioxide on hematite and goethite particle surfaces. Phys. Chem. Chem. Phys. 2007, 9, 5542-5554. [CrossRef] [PubMed]

39. Urupina, D.; Lasne, J.; Romanias, M.; Thiery, V.; Dagsson-Waldhauserova, P.; Thevenet, F. Uptake and surface chemistry of $\mathrm{SO}_{2}$ on natural volcanic dusts. Atmos. Environ. 2019, 217, 116942. [CrossRef]

40. Urupina, D.; Gaudion, V.; Romanias, M.N.; Verriele, M.; Thevenet, F. Method development and validation for the determination of sulfites and sulfates on the surface of mineral atmospheric samples using reverse-phase liquid chromatography. Talanta 2020, 219, 121318. [CrossRef] [PubMed]

41. Arnalds, O.; Dagsson-Waldhauserova, P.; Olafsson, H. The Icelandic volcanic aeolian environment: Processes and impacts-A review. Aeolian Res. 2016, 20, 176-195. [CrossRef]

42. Gislason, S.R.; Hassenkam, T.; Nedel, S.; Bovet, N.; Eiriksdottir, E.S.; Alfredsson, H.A.; Hem, C.P.; Balogh, Z.I.; Dideriksen, K.; Oskarsson, N.; et al. Characterization of Eyjafjallajokull volcanic ash particles and a protocol for rapid risk assessment. Proc. Natl. Acad. Sci.USA 2011, 108, 7307-7312. [CrossRef]

43. Baldo, C.; Formenti, P.; Nowak, S.; Chevaillier, S.; Cazaunau, M.; Pangui, E.; Di Biagio, C.; Doussin, J.-F.; Ignatyev, K.; DagssonWaldhauserova, P.; et al. Distinct chemical and mineralogical composition of Icelandic dust compared to northern African and Asian dust. Atmospheric Chem. Phys. Discuss. 2020, 20, 13521-13539. [CrossRef]

44. Prospero, J.M.; Ginoux, P.; Torres, O.; Nicholson, S.E.; Gill, T.E. Environmental characterization of global sources of atmospheric soil dust identified with the NIMBUS 7 Total Ozone Mapping Spectrometer (TOMS) absorbing aerosol product. Rev. Geophys. 2002, 40, 2-1-2-31. [CrossRef]

45. Marticorena, B.; Chatenet, B.; Rajot, J.L.; Bergametti, G.; Deroubaix, A.; Vincent, J.; Kouoi, A.; Schmechtig, C.; Coulibaly, M.; Diallo, A.; et al. Mineral dust over west and central Sahel: Seasonal patterns of dry and wet deposition fluxes from a pluriannual sampling (2006-2012). J. Geophys. Res. Atmos. 2017, 122, 1338-1364. [CrossRef]

46. Wang, X.; Romanias, M.N.; Pei, Z.; Rousseau, A.; Thévenet, F. Uptake mechanism of acetic acid onto natural gobi dust. ACS Earth Space Chem. 2020, 4, 1650-1662. [CrossRef]

47. Tang, M.; Cziczo, D.J.; Grassian, V.H. Interactions of water with mineral dust aerosol: Water adsorption, hygroscopicity, cloud condensation, and ice nucleation. Chem. Rev. 2016, 116, 4205-4259. [CrossRef]

48. Hatch, C.D.; Wiese, J.S.; Crane, C.C.; Harris, K.J.; Kloss, H.G.; Baltrusaitis, J. Water adsorption on clay minerals as a function of relative humidity: Application of bet and freundlich adsorption models. Langmuir 2012, 28, 1790-1803. [CrossRef] [PubMed]

49. Alleman, L.Y.; Lamaison, L.; Perdrix, E.; Robache, A.; Galloo, J.-C. PM10 metal concentrations and source identification using positive matrix factorization and wind sectoring in a French industrial zone. Atmos. Res. 2010, 96, 612-625. [CrossRef]

50. Maters, E.C.; Delmelle, P.; Rossignol, M.; Ayris, P.M.P.; Bernard, A. Controls on the surface chemical reactivity of volcanic ash investigated with probe gases. Earth Planet. Sci. Lett. 2016, 450, 254-262. [CrossRef]

51. Ayris, P.; Lee, A.; Wilson, K.D.; Kueppers, U.; Dingwell, D.B.; Delmelle, $\mathrm{P}_{\mathrm{S}} \mathrm{SO}_{2}$ sequestration in large volcanic eruptions: High-temperature scavenging by tephra. Geochim. Cosmochim. Acta 2013, 110, 58-69. [CrossRef]

52. Joshi, N.; Romanias, M.N.; Riffault, V.; Thevenet, F. Investigating water adsorption onto natural mineral dust particles: Linking DRIFTS experiments and BET theory. Aeolian Res. 2017, 27, 35-45. [CrossRef]

53. Ibrahim, S.; Romanias, M.N.; Alleman, L.Y.; Zeineddine, M.N.; Angeli, G.K.; Trikalitis, P.N.; Thevenet, F. Water interaction with mineral dust aerosol: Particle size and hygroscopic properties of dust. ACS Earth Space Chem. 2018, 2, 376-386. [CrossRef]

54. Xi, J.; Zhang, S. Adsorption and desorption of Sb(III) on goethite. IOP Conf. Ser. Earth Environ. Sci. 2017, 100, 12145. [CrossRef]

55. Zuo, Y.; Chen, H. Simultaneous determination of sulfite, sulfate, and hydroxymethanesulfonate in atmospheric waters by ion-pair HPLC technique. Talanta 2003, 59, 875-881. [CrossRef] 
56. Ayris, P.; Delmelle, P. Volcanic and atmospheric controls on ash iron solubility: A review. Phys. Chem. Earth Parts A B C 2012, 45-46, 103-112. [CrossRef]

57. Hettiarachchi, E.; Reynolds, R.L.; Goldstein, H.L.; Moskowitz, B.; Rubasinghege, G. Iron dissolution and speciation in atmospheric mineral dust: Metal-metal synergistic and antagonistic effects. Atmos. Environ. 2018, 187, 417-423. [CrossRef]

58. Hettiarachchi, E.; Reynolds, R.L.; Goldstein, H.L.; Moskowitz, B.; Rubasinghege, G. Bioavailable iron production in airborne mineral dust: Controls by chemical composition and solar flux. Atmos. Environ. 2019, 205, 90-102. [CrossRef]

59. Hettiarachchi, E.; Rubasinghege, G. Mechanistic study on iron solubility in atmospheric mineral dust aerosol: Roles of titanium, dissolved oxygen, and solar flux in solutions containing different acid anions. ACS Earth Space Chem. 2019, 4, 101-111. [CrossRef] 